\title{
FAKTOR-FAKTOR YANG BERPENGARUH TERHADAP KEJADIAN HIPERTENSI PADA LANSIA DI WILAYAH KERJA PUSKESMAS MAIWA KAB.ENREKANG
}

\section{Factors Which Have An Effect On To Hypertension Occurence At Lansia In Region Work The Puskesmas Maiwa Kab.Enrekang}

\author{
Yuli Hilda Sari, Usman, Makhrajani Majid, Rasidah Wahyuni Sari \\ (Program Studi Kesehatan Masyarakat Fakultas Ilmu Kesehatan Universitas \\ Muhammadiyah Parepare) \\ Jl. Jendral Ahmad Yani KM.6 Tlp. (0421) 255757 Fax. (0421) 25524 \\ (yulihildasarii@gmail.com)
}

\begin{abstract}
ABSTRAK
Hipertensi disebut silent killer karena sifatnya asimptomatik dan telah beberapa tahun menimbulkan stroke yang fatal atau penyakit jantung. Meskipun tidak dapat diobati, pencegahan dan penatalaksanaan dapat menurunkan kejadian hipertensi dan penyakit yang menyertainya. Penelitian ini bertujuan untuk membuktikan apakah ada tidaknya pengaruh faktor-faktor yang mempengaruhi terhadap kejadian hipertensi pada lansia di Wilayah Kerja Puskesmas Maiwa Kab.Enrekang. Penelitian ini menggunakan penelitian analitik dengan rancangan cross sectional studi, dengan menggunakan Systematic Random Sampling. Data dianalisis dengan uji Chi Square, Koefisien phi dengan $\alpha$ 0,05. Sebanyak 77 lansia yang memenuhi kriteria penelitian, uji chi-square bahwa ada pengaruh tingkat stres terhadap kejadian hipertensi pada lansia $\mathrm{X}^{2}$ hit. 72,616 stres dapat menjadi faktor pencetus, penyebab sekaligus akibat dari suatu gangguan atau penyakit, ada pengaruh bertambahnya usia terhadap kejadian hipertensi pada lansia dengan $\mathrm{X}^{2}$ hit. 34,720 Semakin tinggi umur seseorang semakin tinggi tekanan darahnya, jadi orang yang lebih tua cenderung mempunyai tekanan darah yang tinggi dari orang yang berusia lebih muda.,dan ada pengaruh genetik terhadap kejadian hipertensi pada lansia dengan $X^{2}$ hit. 41,819 Adanya faktor genetik pada keluarga tertentu akan menyebabkan keluarga itu mempunyai risiko menderita hipertensi. Hasil penelitian ini diharapkan lansia dapat mengontrol tingkat stres dengan baik,mengurangi aktivitas yang melelahkan dan teratur melakukan cek tekanan darah, serta rutin mengikuti posyandu lansia.
\end{abstract}

Kata kunci : Tingkat stres, bertambahnya usia, genetik, hipertensi

\section{ABSTRACT}

Hypertension referred by silent killer of because in character asimptomatik and some years have generate the fatal stroke or heart sickness. Though cannot be cured the, prevention and penatalaksanaan can degrade the occurence of hypertension and disease accompanying it. This research aim to to prove whether/what there is not it him Factors influence Influencing to hypertension occurence at lansia in Region Work The Puskesmas Maiwa Kab.Enrekang. This Research use the analytic research with the device of cross sectional study, by using Systematic Random Sampling. Data analysed with the test of Chi Square, Coefficient Phi by ? 0,05. As much 77 lansia fulfilling research criterion, Test the chi-square that there is influence mount the stres to hypertension occurence at lansia X2 hit. 72,616 Stres can become the factor pencetus, cause at one blow effect of trouble or disease, there is influence increase it age to hypertension occurence at lansia by X2 is hit. 34,720 Excelsior old age the its blood pressure excelsior somebody, become 
one who older tend to to have the high blood pressure from one who have age to more muda there is influence genetik to hypertension occurence at lansia by X2 is hit. 41,819 Existence of factor genetik at certain family will cause that family have the risk suffer hypertension. Result of this research expected by lansia can control the storey;level stres by baik,mengurangi regular and tiring activity do/conduct the blood pressure cheque, routine to and also follow the posyandu lansia.

Keyword : Mount the stres, increasing it age, genetik, hypertension 


\section{PENDAHULUAN}

Hipertensi merupakan masalah kesehatan masyarakat di dunia baik negara maju maupun negara berkembang. Hipertensi disebut juga "silent killer" karena pada sebagian kasus tidak menunjukkan gejala apapun. Perkembangan hipertensi berlangsung secara lambat-laun sehingga sering tidak disadari. Hipertensi adalah peningkatan tekanan darah di arteri yang bersifat sistemik dan berlangsung terusmenerus untuk jangka waktu yang lama. Hipertensi tidak terjadi tiba-tiba, melainkan melalui proses yang berlangsung cukup lama. Hipertensi didefinisikan sebagai ratarata tekanan sistolik $\geq 140 \mathrm{mmHg}$, dan tekanan darah diastolik yaitu $\geq 90 \mathrm{mmHg}$. Jadi berdasarkan pengertian di atas dapat disimpulkan bahwa hipertensi adalah tekanan darah yang $\geq 140 / 90 \mathrm{mmHg}$ dengan dua kali pengukuran. Berdasarkan penyebabnya, hipertensi dibagi dalam dua golongan, yaitu hipertensi primer dan hipertensi sekunder. Hipertensi primer adalah suatu kondisi yang jauh lebih sering dan meliputi 95\% dari hipertensi. Hipertensi ini disebabkan oleh berbagai faktor, yaitu beberapa faktor yang efek-efek kombinasinya menyebabkan hipertensi. Hipertensi sekunder, yang meliputi 5\% dari hipertensi. Disebabkan oleh suatu kelainan spesifik pada salah satu organ atau sistem tubuh. ${ }^{1}$

Berdasarkan survei awal yang dilakukan oleh peneliti di Puskesmas Maiwa Kab.Enrekang tahun 2017 menunjukkan bahwa jumlah penderita hipertensi sebanyak 2958 penderita, sekitar $64 \%$ sebanyak 1893 penderita hipertensi adalah lansia dengan perbandingan $31,6 \%$ pria dan $32,4 \%$ wanita. Dimana yang menjadi sasaran peneliti yakni hanya lansia usia petengahan (middle age) yang berumur 45 sampai 59 tahun sekitar $17,5 \%$ dengan jumlah 331 penderita hipertensi. Faktor risiko utamanya rata-rata karena tingkat stres,bertambahnya usia dan faktor genetik (turunan). Atas dasar inilah sehingga peneliti mengangkat judul Faktorfaktor yang Berpengaruh Terhadap Kejadian Hipertesi pada Lansia Di Wilayah Puskesmas Maiwa Kabupaten Enrekang penelitian tersebut dengan harapan para lansia lebih memperhatikan kesehatannya.

Berdasarkan uraian-uraian pada latar belakang di atas untuk meningkatkan mutu pelayanan kesehatan dalam rangka menurunkan jumlah penderita hipertensi dan agar penelitian ini lebih terarah serta mencapai sasaran yang diharapkan, maka dirumuskan beberapa masalah adalah adakah pengaruh tingkat stres terhadap kejadian hipertensi pada lansia di Wilayah Kerja Puskesmas Maiwa Kabupaten Enrekang, adakah pengaruh bertambahnya usia terhadap kejadian hipertensi pada lansia di Wilayah Kerja Puskesmas Maiwa Kabupaten Enrekang dan adakah pengaruh genetik terhadap kejadian hipertensi pada lansia di Wilayah Kerja Puskesmas Maiwa Kabupaten Enrekang. 


\section{METODE PENELITIAN}

Metode yang digunakan dalam penelitian ini adalah menggunakan metode penelitian analitik yakni penelitian yang mencoba menggali bagaimana dan mengapa fenomena kesehatan itu terjadi yakni dimana peneliti harus melakukan perlakuan terhadap variabel bebas. Dengan pendekatan secara cross sectional yaitu suatu rancangan penelitian yang mengkaji dinamika dan mengamati pengaruh antara variabel dependen pada saat bersamaan untuk mengetahui pengaruh faktor pengaruh tingkat stres, bertambahnya usia dan genetik terhadap kejadian hipertensi pada lansia di Wilayah Kerja Puskesmas Maiwa Kabupaten Enrekang.

Populasi dalam penelitian ini adalah lansia dengan jumlah 331 di Wilayah Kerja Puskesmas Maiwa Kabupaten Enrekang. Analisis data adalah mengkaji data yang diperoleh melalui statistik deskriptif dengan menggunkan statistik analitik untuk mengkaji hipotesis. Analisis data dalam penelitian ini adalah dengan mnggunakan teknik sebagai berikut:

\section{HASIL PENELITIAN}

Hasil penelitian menunjukkan bahwa jumlah responden berdasarkan umur di wilayah kerja Puskesmas Maiwa 45-50 tahun sebanyak 58,4\% dan 51-59 tahun sebanyak 41,6\% dimana kelompok umur yang terendah yakni 51-59 tahun. Dan data umum responden berdasarkan tingkat pendidikan di wilayah kerja Puskesmas
Maiwa yang tertinggi SMA/Sederajat sebanyak 35,0 \%, TS sebanyak 14,3\%, TTSD sebanyak 9,1\%, SMP/Sederajat sebanyak 23,4\%, Diploma sebanyak 6,5\% dan Sarjana sebanyak 11,7\%. Distribusi responden berdasarkan tingkat stres yang terbanyak adalah kategori sedang yaitu $55 \%$ responden, sedangkan yang paling sedikit adalah kategori rendah yaitu 5\% responden. Hal ini menunjukkan umumnya tingkat stres responden di wilayah kerja Puskesmas Maiwa masih baik. Sedangkan jumlah responden berdasarkan usia yang terbanyak adalah kategori tidak berisiko yaitu 58,4\% responden adapun yang paling sedikit adalah kategori berisiko yaitu $41,6 \%$ responden. Hal ini menunjukkan umumnya usia responden di wilayah kerja Puskesmas Maiwa tidak berisiko terkena hipertensi.

Responden berdasarkan genetik yang terbanyak adalah kategori tidak berisiko yaitu 55,8\% responden, sedangkan yang paling sedikit adalah kategori berisiko yaitu 44,2\% responden. Hal ini menunjukkan umumnya genetik responden di wilayah kerja Puskesmas Maiwa tidak berisiko terkena hipertensi. Sedangkan untuk tingkat resiko hipertensi kategori tinggi sebanyak 41,6\%, kategori sedang yaitu 51,9 $\%$, paling sedikit adalah kategori rendah yaitu dari 6,5\%. Hal ini menunjukkan umumnya tingkat resiko hipertensi responden di wilayah kerja Puskesmas Maiwa tinggi.

Berdasarkan tingkat stres, terdapat $41,5 \%$ responden dengan tingkat stres 
kategori tinggi dan 52\% responden dengan kategori sedang. . Sedangkan 6,5\% responden dengan kategori rendah. Berdasarkan hasil uji Chi Kuadrat, diperoleh nilai $\mathrm{X}^{2}$ hitung $=51,874$ dan $\quad \mathrm{X}^{2}$ tabel $=$ 3,841 dengan taraf signifikan 5\%. Karena $\mathrm{X}^{2}$ hitung $>\mathrm{X}^{2}$ tabel, ini berarti Ha diterima dan Ho ditolak. Artinya ada pengaruh yang signifikan antara tingkat stres terhadap kejadian hipertensi pada lansia di wilayah kerja Puskesmas Maiwa Kabupaten Enrekang.

Berdasarkan variabel usia, responden yang berisiko tinggi sebanyak 41,6\% responden. Kategori sedang sebanyak 51,9\% responden. Sedangkan kategori rendah sebanyak 6,5\% responden. Berdasarkan hasil uji Chi Kuadrat, diperoleh nilai $\mathrm{X}^{2}$ hitung = 34,720 dan $X^{2}$ tabel $=3,841$ dengan taraf signifikan 5\%. Karena $\mathrm{X}^{2}$ hitung $>\mathrm{X}^{2}$ tabel, ini berarti Ha diterima dan Ho ditolak. Artinya ada pengaruh yang signifikan antara usia terhadap kejadian hipertensi pada lansia di wilayah kerja Puskesmas Maiwa Kabupaten Enrekang. Sedangkan berdasarkan genetik, responden berisiko tinggi sebanyak 41,6\%. Kategori sedang sebanyak 51,9\% responden. Sedangkan kategori rendah sebanyak 6,5\% responden.

\section{PEMBAHASAN}

Berdasarkan hasil penelitian yang diperoleh maka ditemukan adanya pengaruh yang signifikan antara faktor tingkat stres terhadap hipertensi pada Tabel 5 . Berdasarkan hasil uji Chi Kuadrat diperoleh nilai $\mathrm{X}^{2}$ hitung $=51,874$ dan $\quad \mathrm{X}^{2}$ tabel $=$

3,841 dengan taraf signifikan 5\%. Karena $\mathrm{X}^{2}$ hitung $>X^{2}$ tabel, ini berarti Ha diterima dan Ho ditolak. Artinya ada pengaruh yang signifikan antara tingkat stres terhadap kejadian hipertensi pada lansia di wilayah kerja Puskesmas Maiwa Kabupaten Enrekang. Stres adalah tanggapan/reaksi tubuh terhadap berbagai tuntutan atau beban atasnya yang bersifat non spesifik. Stres juga dapat diartikan pola adaptasi umum dan pola reaksi stresor, yang berasal dari dalam di individu maupun dari lingkungannya. Stres dapat menjadi faktor pencetus, penyebab sekaligus akibat dari suatu gangguan atau penyakit. Faktor-faktor psikososial cukup mempunyai arti dari bagi terjadinya stres pada diri seseorang. Faktor-faktor lain yang mungkin mempengaruhi respon terhadap stresor antara lain sifat stresor, pengalaman masa lalu,ekonomi, tipe kepribadian responden sehingga mempengaruhi tinggi rendahnya tingkat stres. Stres terbagi dari 3 tingkatan yaitu stres ringan, stres sedang dan stres berat. Stres sedang dapat memicu terjadinya penyakit, stres sedang terjadi lebih lama, dari beberapa jam hingga beberapa hari. Stressor yang dapat menimbulkan stres sedang pada lansia adalah masalah ekonomi untuk mencukupi kehidupan sehari-hari, kehilangan pasangan hidup, kesekapatan yang belum selesai, beban kerja yang berlebihan.

Berdasarkan dari hasil penelitian adanya tingkat stres yang tinggi juga sangat mempengaruhi terjadinya hipertensi yakni sebanyak 40,3\%. Hipertensi sangat 
mempengaruhi tingkat stres pada lansia karena melalui saraf simpatis yang dapat meningkatkan tekanan darah secara intermiten. Apabila stres berlangsung lama dapat meningkatkan peninggian tekanan darah yang menetap, stres juga dapat meningkatkan kolestrol tinggi, yang mengakibatkangangguan pola makan sehingga dapat menyebabkan malas untuk beraktifitas dan olaraga, hingga mengatasi stres dengan merokok semuanya ini merupakan faktor resiko hipertensi yang dapat terjadi. Dimana tingkat stres responden yang dialami dikarenakan masalah yang ada dalam keluarga yang memicu naiknya emosi yang tidak terkontrol dan ada juga yang tidak mampu diungkapkan hanya dipendam yang mampu mengganggu kesehatan secara mental yang mampu memicu stres tingkat tinggi.

Adapun dari hasil observasi dan wawancara langsung pada responden dalam kategori pola komsumsi tinggi garampun yang menjadi resiko terjadinya hipertensi. Penelitipun secara langsung memberikan informasi dan pengetahuan untuk mewaspadai asupan garam yang berlebih, karena garam merupakan sumber sodium yang utama dan garam adalah faktor pencetus penyebab peyakit tekanan darah tinggi atau hipertensi yang dapat berkembang menjadi penyakit-penyakit kardiovaskuler. Darah tinggi terjadi jika ada peningkatan pembuluh darah yang memaksa kerja jantung untuk memompa darah dan nutrisi. Garam menyebabkan tubuh menahan air dengan tingkat melebihi ambang batas normal tubuh sehingga dapat meningkatkan volume darah dan tekanan darah tinggi lebih tinggi dibandingkan dengan di pedesaan. Hal ini dapat dihubungkan dengan pengaruh stress yang dialami kelompok masyarakat yang tinggal di kota. Stres akan meningkatkan resistensi pembuluh darah perifer dan curah jantung sehingga akan menstimulasi aktivitas saraf simpatis. Adapun stres ini dapat berhubungan dengan pekerjaan, kelas sosial, ekonomi, dan karakteristik personal. Penelitian ini sejalan dengan penelitian yang dilakukan oleh Wahyuningsi ditemukan dengan hasil uji statistik Chi Square didapatkan nilai $\mathrm{x}$ hitung $=1,241<\mathrm{x}$ tabel 0,05 jadi hipotesis diterima sehingga dapat disimpulkan bahwa tingkat stress berpengaruh pada kejadian hipertensi. ${ }^{2}$

Berdasarkan hasil penelitian yang diperoleh maka ditemukan adanya pengaruh yang signifikan antara faktor usia terhadap hipertensi pada Tabel 6 .Berdasarkan hasil uji Chi Kuadrat, diperoleh nilai X2 hitung = 34,720 dan $\quad \mathrm{X} 2$ tabel $=3,841$ dengan taraf signifikan 5\%. Karena X2 hitung > X2 tabel, ini berarti Ha diterima dan Ho ditolak. Artinya ada pengaruh yang signifikan antara usia terhadap kejadian hipertensi pada lansia di wilayah kerja Puskesmas Maiwa Kabupaten Enrekang.

Berdasarkan dari hasil penelitian adanya faktor bertambahnya usia juga mempengaruhi terjadinya hipertensi yakni 41,6\% karena sebagian besar respnden baru 
merasakan gejala hipertensi dengan bertambahnya umur mereka tentu saja sebagian besar dikarenakan pola hidup yang kurang baik dan pola makan yang kurang sehat . Banyaknya faktor resiko peyebab hipertensi mengakibatkan hipertensi merupakan penyakit dengan jumlah penderita yang banyak. Seiring dengan bertambahnya usia menjadi salah satu faktor resiko dari hipertensi. Faktor yang terkait proses manua berisiko hipertensi dikarenakan terjadinya kekakuan pada aorta, peningkatan afterload (membutuhkan daya yang lebih banyal untuk memompa darah dari vertikal) dan peningkatan tekanan vaskuler. ${ }^{3}$ Pertambahan usia menyebabkan adanya perubahan fisikologis dalam tubuh seperti penebalan dinding arteri akibat adanya penumpukan zat kolagen pada lapisan otot, sehingga pembulu darah akan mengalami penyempitan dan menjadi kaku dimulai saat usia 45 tahun. Selain itu juga terjadi peningkatan resistensi perifer dan aktifitas simpatik serta kurangnya sensitivitas baroreseptor (pengatur tekanan darah) dan peran ginjal aliran darah ginjal dan laju filtrasi glomerulus menurun.

Berdasarkan hasil penelitian yang diperoleh maka ditemukan adanya pengaruh yang signifikan antara faktor genetik terhadap hipertensi pada Tabel 7 Berdasarkan hasil uji Chi Kuadrat diperoleh nilai $\mathrm{X}^{2}$ hitung $=41,819$ dan $\quad X^{2}$ tab $=$ 3,841 dengan taraf signifikan 5\%. Karena $\mathrm{X}^{2}$ hitung $>X^{2}$ tabel, ini berarti Ha diterima dan Ho ditolak. Artinya ada pengaruh yang signifikan antara genetik terhadap kejadian hipertensi pada lansia di wilayah kerja Puskesmas Maiwa Kabupaten Enrekang.

Berdasarkan dari hasil penelitian adanya faktor genetik juga sebagian besar mempengaruhi terjadinya hipertensi yakni $44,2 \%$ selebihnya tidak mempengaruhi faktor genetik terjadinya hipertensi sebanyak $55,8 \%$ hanya berbeda $11,6 \%$ saja dimana sebagian besar orang tua riwayat orang tua, saudara nenek atau kakek serta saudara responden juga berisiko terkena hipertensi. Jika seorang dari orang tua kita mempunyai riwayat hipertensi maka sepanjang hidup kita mempunyai $25 \%$ kemungkinan mendapatkannya pula dan jika kedua orang tua kita terkena riwayat hipertensi maka kemungkinan besar kita mendapatkan penyakit hipertensi $60 \%$.

Hipertensi merupakan salah satu gangguan genetik yang bersifat kompleks. Hipertensi esensial biasanya terkait dengan gen dan faktor genetik, dimana banyak gen yang turut berperan pada perkembangan gangguan hipertensi. Faktor genetik menyumbangkan $30 \%$ terhadap perubahan tekanan darah pada populasi yng berbeda. Keturunan atau predisposisi genetic terhadap penyakit merupakan faktor resiko paling utama adanya riwayat keluarga yang menderita hipertensi, kejadian hipertensi lebih baik dijumpai pada kembar monozigot (satu sel telur) daripada heterozigot (berbeda sel telur), apabila salah satu diantaranya menderita hipertensi. Seorang penderita mempunyai sifat genetik hipertensi primer 
apabila dibiarkan secara alamiah tanpa intervensi terapi, bersama lingkungannya akan menyebabkan hipertensinya berkembang dan dalam waktu 30-50 tahun akan timbul tanda dan gejala.

Hasil penelitian ini sesuai dengan teori keturunan karena genetiknya yang meningkat sehingga dapat menyebabkan penyakit hipertensi dan gen yang terkandung didalamnya adalah neurogenik yang secara genetik adalah pemicu timbulnya hipertens. Kondisi ini terjadi ketika individu lahir dari dua individu sehat pembawa gen rusak tersebut, tetapi juga dapat terjadi ketika gen yang rusak tersebut merupakan gen yang dominan. Namun setiap kelainan genetik tidak selalu muncul dalam sisilah keluarga. Kadang - kadang kelainan itu baru muncul setelah ada faktor pencetusnya. Maka dianjurkan para responden apalagi dikalangan lansia yang sudah terkena hipertensi dianjurkan berolaraga karena dapat memobilisasi masa otot sehingga mengakibatkan kontraksi yang berkala yang ringan dan menenangkan. Untuk mewujudkan proses ini otot-otot memompa darah secara aktif sehingga kerja jantung lebih ringan dalam memompa darah, selama olaraga tersebut, tekanan darah sedikit meningkat namun kemudian jantung dan pembuluh darah menjadi terbiasa bekerja dengan tekanan darah yang lebih rendah. Dengan adanya faktor genetik pada keluarga tertentu akan menyebabkan keluarga tersebut mempunyai resiko dua kali lebih besar untuk menderita hipertensi daripada individu yang tidak mempunyai keluarga dengan riwayat hipertensi. Sesuai dari hasil penelitian yang dilakukan di lapangan banyak ditemukan keluarga yang menderita hipertensi diwariskan oleh keturunannya. Ada baiknya mulai sekarang kita memeriksa riwayat kesehatan keluarga sehingga kita dapat melakukan antisipasi dan pencegahan. Ini tidak hanya berlaku pada penyakit hipertensi tetapi juga untuk penyakitpenyakit lain. Bagaimanapun melakukan pencegahan penyakit dan antisipasi jauh lebih baik dari pada melakukan pengobatan. Hal ini sejalan dengan penelitian yang dilakukan oleh Agustina berdasarkan dengan hasil uji statistik menunjukkan bahwa terdapat hubungan bermakna antara genetik (keturunan) dengan hipertensi pada lansia dengan $p=$ value $<0,05$, yakni sebesar 0,008 . Dengan hasil analisis diperoleh pula nilai $\mathrm{OR}=8,850$ artinya lansia dengan riwayat genetik (keturunan) hipertensi mempunyai peluang 8,8 kali menderita hipertensi dibandingkan dengan tidak ada genetik (keturunan). ${ }^{4}$ Hasil penelitian inipun sejalan dengan penelitian Rachman yaitu riwayat keluarga yang memiliki hipertensi merupakn faktor resiko terjadinya hipertensi. $^{5}$

Dalam hasil penelitian tersebut peneliti mendapatkan kebiasaan lansia memiliki kebiasaan merokok rata-rata respnden pria padahal kita ketahui bersama orang yang merokok sangat berisiko terkena penyakit darah tinggi, merokok bisa memicu tekanan darah seseorang menjadi naik secara 
drastis. Untuk anda yang perokok berat sebaiknya mulai sekarang mengurangi aktivitas anda untuk merokok bahkan anda harus berhenti merokok selain bisa menyebabkan tekanan darah menjadi naik, merokok juga bisa menimbulkan berbagai penyakit yang berbahaya seperti paru-paru. Sebagian besar bahkan hampir keseluruhan lansia jarang melakukan olahraga bahkan ada yang sama sekali tidak pernah berolaraga padahal orang yang tidak pernah melakukan olahraga pastinya akan rentan dengan berbagai penyakit contohnya seperti penyakit darah tinggi. Olahraga merupakan hal yang harus dilakukan seseorang jika ingin tubuh yang sehat karena dengan melakukan olahraga tubuh akan menjadi bugar dan bisa mencega terjadinya berbagai penyakit yang berbahaya,olahraga sangat bagus untuk kesehatan jantung agar bisa memompa darah sehingga peredaran darah didalam tubuh menjadi lancar dan pastinya tekanan darah tubuh akan menjadi normal.

\section{KESIMPULAN DAN SARAN}

Dari hasil penelitian dan pembahasan yang dilakukan mengenai ada pengaruh atau tidak ada pengaruh tingkat stres,usia dan genetik terhadap kejadian hipertensi pada lansia di Wilayah Kerja Puskesmas Maiwa Kabupaten Enrekang. Ada pengaruh tingkat stres terhadap kejadian hipertensi pada lansia di Wilayah Kerja Puskesmas Maiwa Kabupaten Enrekang, ada pengaruh usia terhadap kejadian hipertensi pada lansia di Wilayah Kerja Puskesmas Maiwa Kabupaten Enrekang, ada pengaruh genetik terhadap kejadian hipertensi pada lansia di Wilayah Kerja Puskesmas Maiwa Kabupaten Enrekang.

Adapun saran dalam penelitian ini Diharapkan lansia dapat mengontrol tingkat stres dengan baik,mengurangi aktivitas yang melelahkan dan teratur melakukan cek tekanan darah, serta rutin mengikuti posyandu lansia. Dalam pelayanan kesehatan hendaknya petugas kesehatan yang bersangkutan dapat menyelenggarakan kerjasama dengan lintas sektor yang terdekat dengan masyarakat, dalam upaya deteksi dini serta penyuluhan hipertensi dan penyakit tidak menular tertentu lainnya. Upaya ini bisa dilakukan dengan menyediakan sarana informasi yang mudah diakses masyarakat seperti leaflet dan poster tentang faktor resiko hipertensi . Diharapkan keluarga baik anak maupun saudara terdekat untuk senantiasa memberikan motivasi pada lansia karena dukungan keluarga sangat penting bagi lansia. Memberikan motivasi pada lansia untuk dapat mengontrol tingkat stresnya dan selalu memonitor kepada lansia untuk melakukan cek tekanan darah secara rutin dan Bagi peneliti selanjutnya sebaiknya untuk penilaian tingkat stres pada lansia dilakukan bahasa yang mudah dan dapat dipahami oleh lansia. 


\section{DAFTAR PUSTAKA}

1. Azizah L M. Keperawatan Lanjut Usia. Edisi pertama. Yokyakarta: Nuhu Medika; 2011.

2. Wahyuningsih. Tingkat Stres.Jakarta: Nuhu Medika; 2013.

3. Sofia. Peningkatan Tekanan Vaskuler.Yogyakarta: Graha Ilmu; 2014.

4. Agustina. Perbandingan Genetik dan Hipertensi. Jakarta Salemba Medika; 2014.

5. Rahman. Faktor Resiko Hipertensi.Jakarta: Nuhu Medika; 2012.

6. Depertemen Kesehatan. Laporan Hasil Riset Kesehatan Dasar (Riskesdes) Indonesia. Depkes RI: Jakarta; 2013.

7. Hawari D. Manajemen Stres Cemas dan Depresi. Jakarta : FKUI; 2011.

8. Khotimah. Tingkat Stres Penderita Hipertensi.Jakarta: Nuhu Medika; 2015.

9. Lucky.A. Hipertensi The Silent Killer. Jakarta: Yayasan Penerbitan Ikatan Dokter Indonesia; 2010.
10. Nursalam Dan Efendi, F. Pendidikan Dalam Keperawatan. Jakarta : Salemba Medika; 2009.

11. Maryam R. Siti. Mengenal Usia Lanjut dan Keperawatannya. Jakarta : Salemba Medika; 2010.

12. Saleh. Tingkat Stres Penderita Hipertensi. Jakarta: Salemba Medik; 2015.

13. Sugiyono. Teknik Sampling Untuk Penelitian Kesehatan. Yogyakarta: Graha Ilmu; 2012.

14. Sugiyono. Metode Penelitian Administrasi.Yogyakarta: Graha Ilmu; 2011.

15. Wicaksana A. Rekam Medis dan Kinerja Puskesmas. Cermin Dunia Kedokteran; 2013.

16. WHO. Clinician's Manual Hypertension and the E;derly. London: Science Press; 2009.

17. Zulfahmi. Penanda DNA Untuk Analisis Genetik. Agroteknologi; 2013: $3(2)$

41-52 


\section{LAMPIRAN}

Tabel 1 Distribusi responden berdasarkan umur dan tingkat pendidikan

\begin{tabular}{lcc}
\hline Umur (tahun) & Frekuensi (f) & Persentase (\%) \\
\hline $45-50$ & 45 & 58,4 \\
$51-59$ & 32 & 41,6 \\
\hline Tingkat Pendidikan & Frekuensi(f) & Persentase(\%) \\
\hline TS & 11 & 14,3 \\
TTSD & 7 & 9,1 \\
SMP/Sederajat & 18 & 23,4 \\
SMA/Sederajat & 27 & 35,0 \\
Diploma & 5 & 6,5 \\
Sarajana & 9 & 11,7 \\
\hline Total & 77 & 100,0 \\
\hline
\end{tabular}

Sumber : Data Primer (2018)

Tabel 2. Distribusi responden berdasarkan tingkat stres

\begin{tabular}{|c|c|c|}
\hline Tingkat stres & Frekuensi (f) & Persentase $(\%)$ \\
\hline Tinggi & 31 & 40,3 \\
\hline Sedang & 44 & 57,3 \\
\hline Rendah & 2 & 2,6 \\
\hline Total & 77 & 100,0 \\
\hline
\end{tabular}

Sumber : Data Primer (2018)

Tabel 3. Distribusi responden berdasarkan usia

\begin{tabular}{lcc}
\hline Usia & Frekuensi (f) & Persentase (\%) \\
\hline Berisiko & 32 & 41,6 \\
Tidak berisiko & 45 & 58,4 \\
\hline \multicolumn{1}{c}{ Total } & 77 & 100,0 \\
\hline
\end{tabular}

Sumber : Data Primer (2018)

Tabel 4. Distribusi responden berdasarkan genetik

\begin{tabular}{lcc}
\hline Genetik & Frekuensi (f) & Persentase (\%) \\
\hline Berisiko & 34 & 44,2 \\
Tidak berisiko & 43 & 55,8 \\
\hline \multicolumn{1}{c}{ Total } & 77 & 100,0
\end{tabular}

Sumber : Data Primer (2018)

Tabel 5. Distribusi responden berdasarkan tingkat resiko hipertensi

\begin{tabular}{|c|c|c|}
\hline Tingkat resiko & Frekuensi (f) & Persentase (\%) \\
\hline Tinggi & 32 & 41,6 \\
\hline Sedang & 40 & 51,9 \\
\hline Rendah & 5 & 6,5 \\
\hline Total & 77 & 100,0 \\
\hline
\end{tabular}

Sumber : Data Primer (2018) 
Tabel 6. Pengaruh tingkat stres terhadap kejadian hipertensi pada lansia

\begin{tabular}{|c|c|c|c|c|c|c|c|c|c|}
\hline \multirow{3}{*}{$\begin{array}{l}\text { Tingkat } \\
\text { stres }\end{array}$} & \multicolumn{6}{|c|}{ Hipertensi } & \multirow{3}{*}{\multicolumn{2}{|c|}{$\begin{array}{l}\text { Total } \\
\mathrm{n} \%\end{array}$}} & \multirow[b]{3}{*}{$\mathrm{X}^{2}$ hitung } \\
\hline & \multicolumn{2}{|c|}{ Tinggi } & \multicolumn{2}{|c|}{ Sedang } & \multicolumn{2}{|c|}{ Rendah } & & & \\
\hline & $\mathrm{n}$ & $\%$ & $\mathrm{n}$ & $\%$ & $\mathrm{n}$ & $\%$ & & & \\
\hline Tinggi & 23 & 29,9 & 7 & 9,1 & 1 & 1,3 & 31 & 40,3 & $=51,874$ \\
\hline Sedang & 9 & 11,6 & 33 & 42,9 & 2 & 2,6 & 44 & 57,1 & $\mathrm{X}^{2}$ tabel \\
\hline Rendah & 0 & 0 & 0 & 0 & 2 & 2,6 & 2 & 2,6 & $=3,841$ \\
\hline Total & 32 & 41,5 & 40 & 52 & 5 & 6,5 & 77 & 100,0 & \\
\hline
\end{tabular}

Tabel 7. Pengaruh usia terhadap kejadian hipertensi pada lansia

\begin{tabular}{|c|c|c|c|c|c|c|c|c|c|}
\hline \multirow{3}{*}{ Usia } & \multicolumn{6}{|c|}{ Hipertensi } & \multirow{3}{*}{$\begin{array}{l}\text { Total } \\
\mathrm{n}\end{array}$} & \multirow{3}{*}{$\%$} & \multirow{6}{*}{$\begin{array}{l}\mathrm{X}^{2} \text { hitung } \\
=34,720 \\
\mathrm{X}^{2} \text { tabel } \\
=3,841\end{array}$} \\
\hline & \multicolumn{2}{|c|}{ Tinggi } & \multicolumn{2}{|c|}{ Sedang } & \multicolumn{2}{|c|}{ Rendah } & & & \\
\hline & $\mathrm{n}$ & $\%$ & $\mathrm{n}$ & $\%$ & $\mathrm{n}$ & $\%$ & & & \\
\hline Berisiko & 25 & 32,5 & 4 & 5,2 & 3 & 3,9 & 32 & 41,6 & \\
\hline Tidak berisiko & 7 & 9,1 & 36 & 46,7 & 2 & 2,6 & 45 & 58,4 & \\
\hline Total & 32 & 41,6 & 40 & 51,9 & 5 & 6,5 & 77 & 100,0 & \\
\hline
\end{tabular}

Sumber : Data Primer (2018)

Tabel 8. Pengaruh genetik terhadap kejadian hipertensi pada lansia

\begin{tabular}{|c|c|c|c|c|c|c|c|c|c|}
\hline \multirow{3}{*}{ Genetik } & \multicolumn{6}{|c|}{ Hipertensi } & \multirow{2}{*}{\multicolumn{2}{|c|}{ Total }} & \multirow{6}{*}{$\begin{array}{l}\mathrm{X}^{2} \text { hitung } \\
=41,819 \\
\mathrm{X}^{2} \text { tabel } \\
=3,841\end{array}$} \\
\hline & \multicolumn{2}{|c|}{ Tinggi } & \multicolumn{2}{|c|}{ Sedang } & \multicolumn{2}{|c|}{ Rendah } & & & \\
\hline & $\mathrm{n}$ & $\%$ & $\mathrm{n}$ & $\%$ & $\mathrm{n}$ & $\%$ & & $\%$ & \\
\hline Berisiko & 28 & 36,4 & 5 & 6,5 & 1 & 1,3 & 34 & 44,2 & \\
\hline Tidak berisiko & 4 & 5,2 & 35 & 45,4 & 4 & 5,2 & 43 & 55,8 & \\
\hline Total & 32 & 41,6 & 40 & 51,9 & 5 & 6,5 & 77 & $\overline{100,0}$ & \\
\hline
\end{tabular}

